Article

\title{
Renewable Energy Project as a Source of Innovation in Rural Communities: Lessons from the Periphery
}

\author{
Sorin Cebotari * and Jozsef Benedek * \\ Babes-Bolyai University, Faculty of Geography, Clinicilor street, 5-7, Cluj-Napoca 400006, Romania \\ * Correspondence: Sorin.cebotari@outlook.com (S.C.); jozsef.benedek@ubbcluj.ro (J.B.) \\ Academic Editor: Francesco Asdrubali \\ Received: 16 January 2017; Accepted: 22 March 2017; Published: 28 March 2017
}

\begin{abstract}
Renewable energy projects (REPs) are viewed as a resource for the development of rural, peripheral communities. Going beyond the simplistic understanding of renewable energy technology as an independent variable, the current study looks into what the interaction between renewables and host communities brings in terms of innovation and development. Relying on a combination of primary and secondary data, both qualitative and quantitative, we observed that for the case of northwest Romania the fast development of REPs had no impact on classic economic indicators such as employment or revenue to the local budget. Looking closely at the impact on innovation as an important explanatory factor of peripheralization, in the majority of researched cases we saw no technical nor policy-related innovation associated with REPs. The presence of a privately-owned project in the territory of the community acted as a possible catalyst for considering developing their own REPs however. Owning a renewable energy project at the same time proved to have a positive impact on policy-related innovation. Moreover, communities that developed and manage their own REPs seem also to be more interested in changing the existing technological arrangements as well.
\end{abstract}

Keywords: renewable energy projects; peripheralization; innovation; development

\section{Introduction}

In the last decade, we have witnessed the fast development of renewable energy projects (REP) [1-3]. Given the fact that majority of renewable energy projects are deployed in rural areas [4] it was stressed that those have a positive impact on the development of rural settlements [3-6]. Some studies argued that renewable energy projects can increase the revenues to the local budget and decrease the unemployment in rural areas [4,7], others claimed that renewable energy projects can have a positive impact on the demographics, agricultural development, or level of social capital [5,6,8-12]. The main argument of those studies is that further development of renewable energy projects will lead also to the development of communities where projects are located. Challenging the above-mentioned assumptions, we consider that there is lack of contextualized understanding of the relationship between REPs and their host communities. More exactly, we plead for a more refined understanding of rural development, thus re-assessing the potential impact of the renewable energy projects on rural development. We believe that looking only at several dispersed variables such as employment, revenues, or demographics cannot offer a full picture of rural development. While the indicators are still important to address we have to understand the underlying dynamics that influence development. The current paper understands development or under-development as a component part of the peripheralization process. We can define the peripheral position, which is the result of peripheralization processes "as being a structurally embedded constellation of conditions, which results in limited access to generally available and desirable resources (material or symbolic) for the people and groups affected, leaving them with restricted room for autonomous action" [13]. The peripherality concept offers us 
only the static view of a given situation. In order to understand the dynamics that lead a community to this position, we have to look at peripheralization dynamics, which are the processes that create this constellation of conditions and are determined by the lack of innovation capacity in local communities. In this way, peripheralization serves as a conceptual umbrella that allows us to tackle complex problems related to the development of rural communities focusing on the dynamics of innovation.

Our main assumption is that REP development is strongly linked to the host community's attitude and interaction with it [14-16]. Through constant interaction with the host communities, technology can be shaped and changed in accordance with the needs of the community it is deployed in [15]. By changing or adapting the existing technological settings, the host community develops an innovative behavior which might have a strong and lasting impact on peripheralization dynamics. This co-evolution of social and technical systems can also lead to more locally-based grassroots innovation movements [17].

Given the above-mentioned points, our paper aims to understand the relationship between REPs and innovation capacity in the rural communities of northwest Romania. To answer the main objective of this paper, we have to address two basic questions, specifically how can we conceptualize and operationalize innovation capacity for the rural communities and what are the mechanisms through which an REP could influence the innovation capacity in rural areas?

Northwest Romania is an interesting case to look at because it has had a fast increasing number of operating renewable energy projects in recent years [18]. Only for the solar power projects there is an increase from zero projects in 2010 to 97 by 2015 [19]. While the fast development of renewable projects is concentrated mostly in rural areas, those areas are also characterized by peripheralization dynamics [20,21]. That offers us an ideal opportunity to observe and understand the way in which the renewable energy projects interacted with those communities and whether it had any effects on the innovation capacity and the subsequent peripheralization of rural areas.

Starting with the definition and discussion of the main concepts, the theoretical part of our paper will also explore the possible connection between theories of technological development and the concept of peripheralization. Relying on the theoretical argument, we design a research methodology which allowed us to test the relationship between the two processes on different layers. Collected data will be presented and discussed in the third part of the paper.

\section{Theoretical Background}

\subsection{Core-Periphery Structures-Defining Peripheralization}

Since the influent work of Immanuel Wallerstein [22], the strong spatial differentiation of uneven development is often described and analyzed by using the biased concept of "core-periphery". There are two main groups of theories regarding the establishement and evolution of core-periphery structures [13,23-26]: 'structuralist theories' (polarization and dependency theories, world system theory) consider regions from a global point of view, the regional development is determined by macroeconomical and macropolitical structures and by the positioning of the regions in a global core-periphery system. As a consequence, the development of regions hinges upon structural and historical conditions. The reason for the underdevelopment of certain regions is the development of the core regions. The tendency of acquiring a higher economic status is hindered by the global competition between regions, which is dominated by the core regions. 'Regionalist theories' (regulation theory, evolutionary theories, new regionalism) offer a locally and territorially-rooted explanations for regional development, where the regions dispose about enough endogenous capabilities to shape their own development paths. Therefore, the sources of regional development are offered by the internal capacities of the regions and by the interregional relations. Each region tends to go through the same evolutionary phases from agrarian society to industrial- and post-industrial societies. The regional differences from this general model are of historical (crucial historical events) or adaptational and innovational nature. 
In this latter group, a new insight in the development of core-periphery structures is offered by the evolutionary approach in economic geography (evolutionary economic geography). The main focus of this approach is on the emergence of new regional growth paths and the evolution of the economic landscape [27]. In this framework, the social agency is always geographically and historically situated, conditioned by a multiscalar socio-institutional context [28]. In an influential paper, Martin [28] argues for the integration of path dependence into a more general theory of local and regional economic adaptation. In this sense, Dawley [29] (p. 92) has formulated one of his main conclusions: "the challenge still remains to specify further the contexts of 'enabling' or 'constraining' environments and to establish greater clarity and specification of the causal factors that explain the creation and geographic diversity of new paths". Given these circumstances, a central open question remains as to how peripheral localities and regions can move from being constraining environments to being enabling environments. Adopting an evolutionary theoretical perspective, processes of creation of new development paths for peripheries are the focus of our paper. Peripheralization in this context represents a dynamic process of marginalization of rural areas as an effect of deprivation from access to innovation and technological development. Specifically, we look closely to the economic factors influencing the peripheralization process. As argued by Kuhn [30] (p. 5), theories of economic peripheralization focus the concept of innovation, "the 'lack of innovation' being a core factor which explains the economic processes of peripheralization". Therefore, our paper defines peripheralization as a dynamic process characterized by the lack of innovative capacity which results in limited access to generally available and desirable resources (economic growth or impact upon the political agenda setting) for the people, groups, and localities affected, leaving them with restricted room for autonomous action. Innovative behavior in this way is one of the key indicators of de-peripheralization dynamics in rural areas.

\subsection{Technology Development-Socially Constructed Character of REP}

Renewable energy can be defined as "a set of multiple hardware sharing one key characteristic - that through generating usable energy in the form of electricity or heat, the resource base is not depleted or significantly diminished" [31] (p. 460). Based on this definition, renewable energy projects can take different hardware forms depending on the technology they rely upon. The hardware arrangement is accompanied by a software social integration of technology which is "an infrastructural organization through which alternative renewable energy hardware are utilized and given purpose and meaning" [31] (pp. 459-460). Previous studies focused primarily on the hardware portion of renewable energy projects $[4,6,7,9]$ considering a renewable energy project an independent variable that could either lead or not lead to the development of the host community. We believe however that renewable energy projects are flexible technological arrangements "which have emerged contingently in particular contexts and which mirror wider social, economic and technical relations and processes" [31] (p. 459) and are in constant evolution and transformation being constructed through a series of interactions with the society in which they are placed [32]. The socially constructed character of renewable energy projects offers a possible way to trace their relationship with the rural communities and possible effects on peripheralization dynamics. Simply said, if the host community manages through a series of interactions with the new technology to adapt the hardware and software parts to its own requirements, then it can be seen as a showcase of innovative behavior.

\subsection{Renewable Energy Projects-Opportunity for Innovation}

As showed in Figure 1, we see two distinct ways of conceptualizing the possible relationship between host community and the deployed project: impact on classic development indicators and impact on innovation capacity of the host community. As suggested by earlier studies, the deployment of a renewable energy project can have an impact on classic economic indicators, thus it should be considered once discussing about the relationship. Nevertheless, taking into account the socially-constructed character of technology, we believe the community-renewables relationship holds important potential in increasing innovation capacity of the host community. 


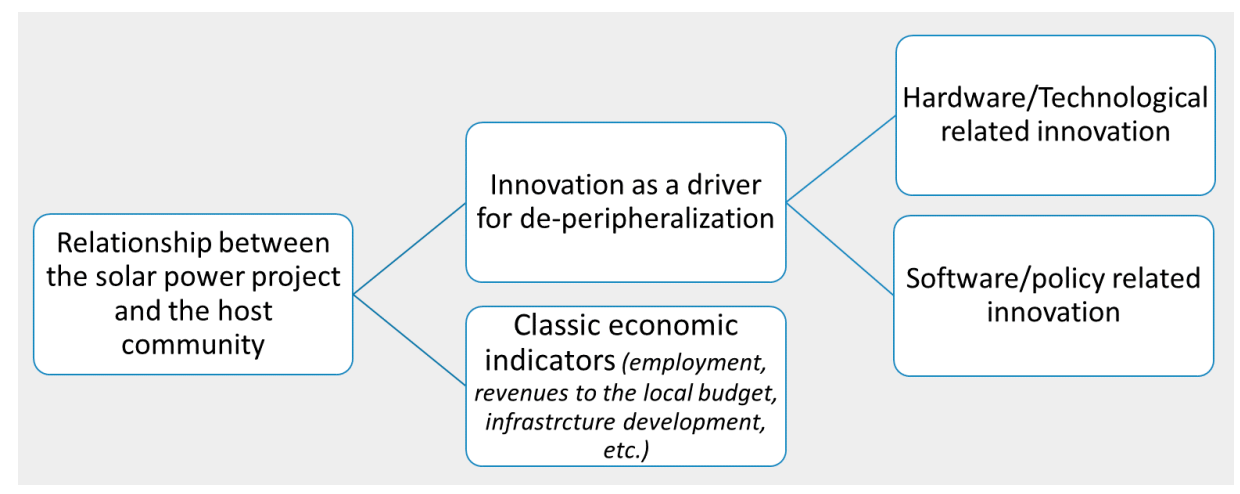

Figure 1. Interaction paths—solar power project and host community.

Starting from the evaluation and assessment of their own energy resources, and continuing with their harvesting for personal and commercial usage, a village can display a high degree of economic, administrative, and institutional innovation [33,34]. Innovative action can take two different forms, as suggested by Walker and Cass [31]: technology/hardware-related innovation and software/policy-related innovation. Technology-related innovation refers to the capacity of a community to change the way in which they manage their energy resources by influencing the existing technical arrangements. Decentralized generation is a good example of possible hardware innovation and refers to a technical arrangement which allows locally-produced energy to be delivered directly to the final consumer, avoiding a national transportation system [35]. While it is not a new technological solution, this type of generation is not wide-spread due to over-centralization of the existing energy system [15,34] which is also the case of Romania, where existing legislation encourages connection to the national transportation network as a preferable technical solution [36-38].

Software or administrative/policy related innovation refers to the innovative behavior in the field of local public policies concerning the management and use of renewable energy sources that can lead to a more opened process of deliberation involving both citizens and local authorities [39]. Software innovation initiatives can challenge the existing management structure, asking for larger possibilities to influence the distribution of the project benefits. It can be considered an innovation because it changes the way in which technology is conceptualized and utilized by local communities. Even if the technology remains the same, the social software impact can change the way in which the project works and the way the benefits are redistributed.

Relying on this understanding of renewable energy-related innovation, our paper focuses on four distinct dimensions: project ownership, access and direct usage of the produced energy, engagement in shaping the existing policy arrangements, and intentions to develop and deploy renewable energy projects.

\section{Materials and Methods}

\subsection{Case Selection}

We collected data from the northwest region of Romania, one of the eight development regions of Romania, characterized by a low level of urbanization ( $52 \%$ of total population lives in 43 towns) and the existence of a large rural periphery, comprising 1800 villages. In addition, the selected region had a ten-fold increase in the quantity of electricity generated from renewable energy sources in the period 2010-2015 [18]. (We refer to renewable energy sources in this context as to all solar, wind, biomass and micro-hydro power plants (less than $10 \mathrm{MW}$ installed capacity) who are entitled to state support through the "Green certificate scheme". Hydro power plants with an installed capacity larger than $10 \mathrm{MW}$, while still considered renewables, are not entitled to a state support scheme and are therefore excluded from our analysis). As shown in the Figure 2, the northwest region is also one of the 
leading regions when it comes to the shares of implemented solar power projects at the national level. We looked at solar power projects because these were the fastest growing type of projects implemented at the small scale, mostly in rural areas. According to the data from Transelectrica-National Transport System Operator, in northwest Romania-in 2010 there were no registered solar power projects [19]. However, by 2015 there were already 97 working projects located in 68 rural settlements across the region [19].

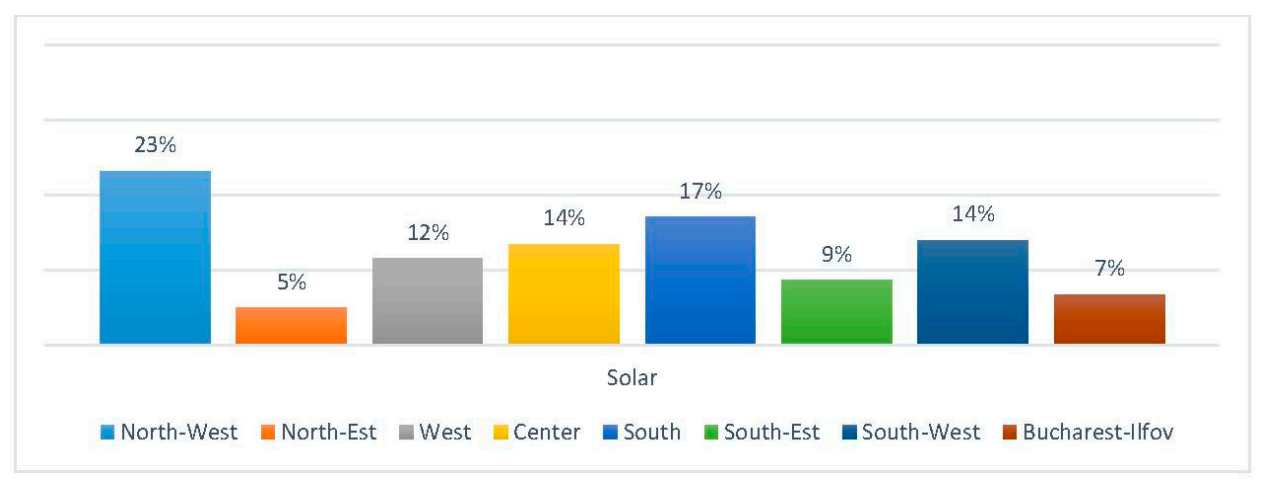

Figure 2. Proportion of implemented solar power projects by each development region (source: own draft based on [19]).

This fast evolution offers an ideal opportunity to observe the way in which solar power projects interacted and affected the host communities.

In order to analyze the main characteristics of the relationship between solar power projects and innovation at the local level, we had a difficult task of operationalizing the concepts of technological (hardware) and administrative (software) innovation. Table 1 summarizes the way in which we operationalized these theoretical concepts and the measurements we used in our questionnaire (Appendix A) in order to assess the possible impact on innovation:

Table 1. Operationalization of hardware and policy innovation (source: own draft based on [31]).

\begin{tabular}{|c|c|}
\hline Theoretical Concept & Concept Operationalization in the Questionnaire \\
\hline $\begin{array}{l}\text { Technological/Hardware innovation } \\
\text { - } \quad \text { Alternative usage of energy } \\
\text { - } \quad \text { Ownership of the technology }\end{array}$ & $\begin{array}{l}\text { - Ownership (Who is the owner of the project? Is the owner from } \\
\text { the local community?) } \\
\text { Energy usage (Who consumes the produced energy? Can the } \\
\text { energy be accessed by local actors/consumers?) }\end{array}$ \\
\hline $\begin{array}{l}\text { Administrative/Software innovation } \\
\text { - } \quad \text { Public involvement in deploying a } \\
\text { locally owned REP } \\
\text { Developing alternative ways to } \\
\text { institutionalize the relationship } \\
\text { between the local authority and } \\
\text { the project. } \\
\text { - Active involvement in decision } \\
\text { making and support of REP } \\
\text { initiatives. Political power over } \\
\text { agenda setting }\end{array}$ & $\begin{array}{l}\text { - } \\
\text { - } \\
\text { considering initiating own RES project (Do public authorities } \\
\text { Pressure from the local level to change the existing technological } \\
\text { or policy arrangements (Can you use the locally-produced energy? } \\
\text { Do you want to change the system? Are there any negotiations in } \\
\text { order to change the existing situation?) } \\
\text { Weight of the local authorities in the negotiation regarding the } \\
\text { deployment of the REP (Who had the final say regarding project's } \\
\text { placement? Have you encouraged the deployment of the project? } \\
\text { How important was local authority's say in the deployment of the } \\
\text { project?) } \\
\text { Involvement of the local authorities in the project's deployment } \\
\text { (Did you know the investor before the implementation of the } \\
\text { project? How did the developer acquire the land for the project?) }\end{array}$ \\
\hline
\end{tabular}

REP: Renewable energy project. RES: Renewable energy sources.

From the total number of 1800 villages from northwest Romania there are 68 villages that deployed solar power projects between 2010 and 2015, which is a quite impressive number taking into account the short period of time and the complete lack of experience in this field. Using the direct questionnaire technique (see Table 1), we contacted the local mayor's office asking to discuss about the project with 
the responsible person from local authorities' side. In case there was no designated person for the interaction with the project, we asked to speak with the mayor.

Through our survey, we wanted to assess two distinct types of impact-perceived impact on development indicators and impact on innovation capacity of the rural areas. Certainly, the perceived impact can be biased or skewed by personal attitudes of a given public authority toward the project. However, our research looks at 28 different localities, thus we believe that overall we will be able to reproduce a truthful picture about the attitudes of local authorities regarding REPs' impact.

\subsection{Development Indicators}

For the variables 'employment' and 'revenues to the local budget' we decided to compare local the authority's view with the official statistical data. To observe if there was a change in employment or budget revenues for localities with deployed solar power projects we compared the variation of the two variables for the period 2010-2014 for villages with implemented solar power projects with the variation of the same variables for the same period for villages without a deployed project. The data source for employment numbers was the National Institute for Statistics [40], respectively for the incomes to the local budget we relied on data provided by the Ministry of Regional Development and Public Administration [41]. To compare the two groups of villages on the variation of the two indicators we used a series of Welch two sample $t$-tests which is ideal for our case, since they are robust to different sample sizes and unequal variance [42].

\section{Results and Discussion}

Out of 68 localities with deployed renewable energy projects we were able to reach 52 local authorities and ask them about the projects. The first observation that surprised us was the lack of knowledge about the projects from the authorities' side. From 52 local authority representatives, only 28 answered that there was a project on the territory of their village, 11 answered that they knew nothing about a solar power project, 9 confirmed that there was a project but it was not active anymore, while 4 representatives insisted that there was no such project at all.

We contacted public authorities based on Transelectrica's data which lists only projects that have a technical connection notice. A connection notice can be issued only when the project has, amongst other things, a construction notice from the local authorities, to prove that they own the land or they rented it for a longer period as well as the company's registration certificate from the National Chamber of Commerce [43]. The project would need, therefore, at least two different notices from the local authority (the construction notice and the land ownership notice) thus it is quite odd that we see this misfit between Transelectrica's data and the information provided by the local authorities. A possible explanation of this situation could be the fact that the required notices where obtained by the company from the previous rural administration, so after the local elections in 2012 and changing of the local administration the new authorities will not recall it. That they do not have any information about the project is quite important in itself. It shows that, at least for those 24 communities with registered renewable energy projects, local authorities have no interaction with the project. In practical terms, it means that the local budget gets no contributions from those projects, there are no active community projects in which the investor is involved, shortly, there is no interaction between the renewable energy project and the local community.

\subsection{Perceived Impact on the "Classic" Development Indicators}

For those communities which confirmed the existence of a working solar power project we looked closer to their interaction with that project mapping the possible impact the project had on the innovation capacity of the community and on development indicators.

In our questionnaire, we asked public authorities to evaluate on a scale from 1 to 10 (where 1 mean no impact and 10 strong, positive impact) the impact renewable energy projects had on: infrastructure 
development, revenues to the local budget, employment, non-RES (Renewable Energy Sources) related investments in their community, and investments in RES projects at the local level.

Figure 3 summarizes the average score for each of the six variables given by the local authorities $(N=28)$. Overall, they saw a low impact on any of the solar power project on development indicators.

As we can see from Figures 4 and 5, the distribution of scores for economic indicators and following investments is clearly skewed toward the left side, confirming the data from Figure 3. These results come as a contradiction to previous studies and show projects on economic development of their communities.

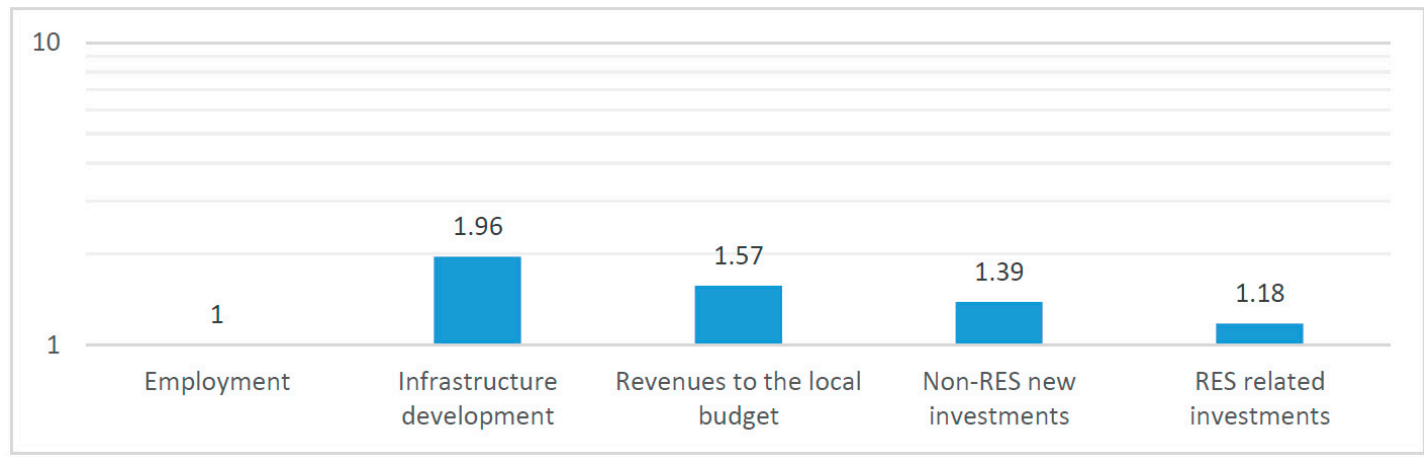

Figure 3. Impact of REP on socio-economic development variables (local authorities' view).

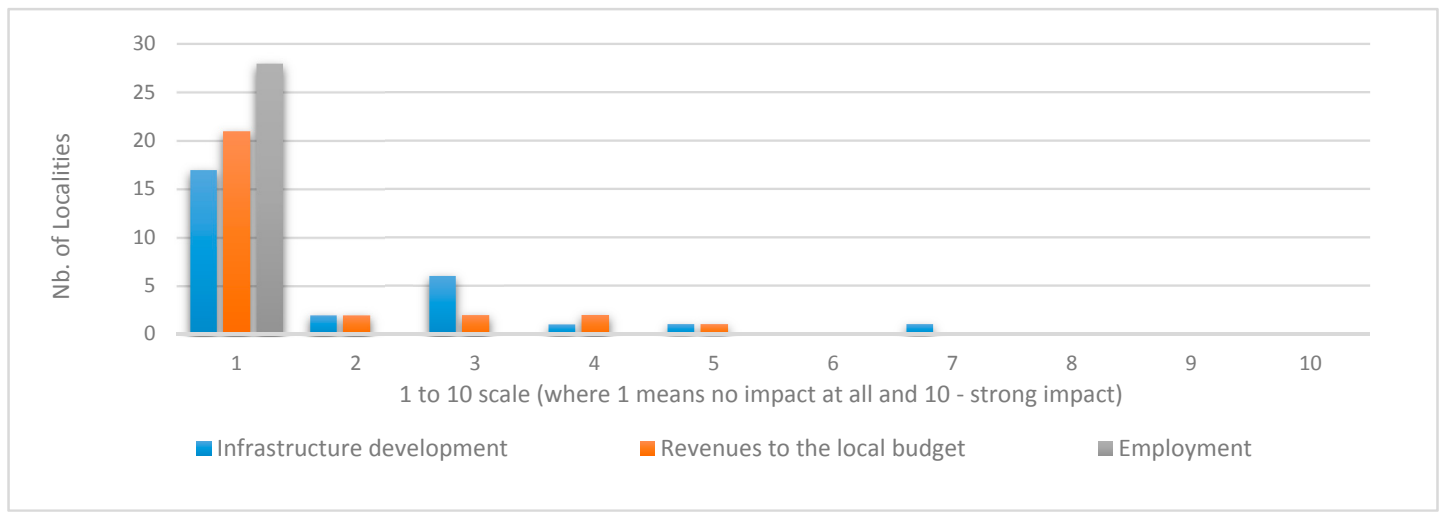

Figure 4. Distribution of answers on REP impact (economic indicators).

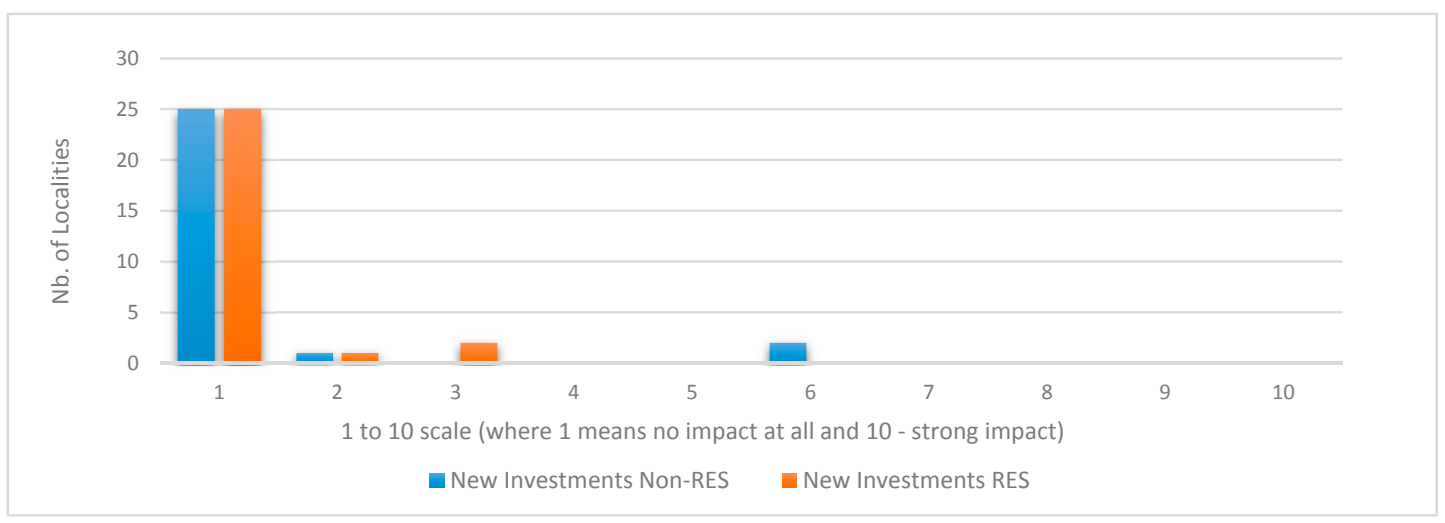

Figure 5. Distribution of answers on REP impact (following investments).

We completed the local authority's view with a two sample $t$ test which compared villages with deployed solar power projects with villages without such projects on the variance of employment and 
revenues to the local budget from 2010 to 2014. For our analysis, we took an alpha level of 0.05 , the skew is $<2$ and the kurtosis $<5$ for both variables. (The selected Alpha level of 0.05 indicates a probability of $5 \%$ of rejecting the null hypothesis when it is true. In other words we can say with $95 \%$ certainty that the produced results are accurate. Skewness indicator measures the symmetry of the data set, meaning the right part of the graph being symmetrical to the left side, for the values comprised between -2 and 2 the distribution is considered symmetrical. Kurtosis on the other hand measures how tailed is the data, values higher or lower than 5 indicate a highly tailed distribution with a lot of outliers. For our data, both skewness and kurtosis values satisfy the basic assumptions for running a two sample $t$-test). Thus, comparing the villages with implemented solar power projects $(N=28)$ with villages without an implemented project but with an attested solar power potential $\left(>1250 \mathrm{kWh} / \mathrm{m}^{2} /\right.$ year, $\left.N=181\right)$ from the northwest region, we found no statistically significant difference between the two groups. The presence of the solar power project did not changed the evolution of the employment and revenues to the local budget variables, confirming local authorities' view as well.

Relying on two different data sources, we can say that solar power projects in northwest Romania have no impact on classic economic indicators of development. Moreover, local authorities do not see renewable energy projects as a resource that can enhance development.

It is important to highlight that all the variables refer to the local township level. It does not mean therefore that the REP fail to produce an impact on any of the mentioned variables, it just does not produce the effects locally, at the community level. While the project might certainly employ engineers or managers for the solar park, it is a high skilled workforce that are outsourced usually from urban centers and will come once or twice a week to the site in order to have the usual maintenance work. This type of employment, while certainly important, does not directly affect the well-being of the local community, an effect that was also mentioned by Frondel et al. in the case of Germany [44].

\subsection{Solar Power Projects and Innovation in Rural Communities}

\subsubsection{Ownership and Local Community Involvement in Deployment of the Project}

Ownership of the technology is important when evaluating the possible innovative practices brought by the project. A project owned by a local business agent or by the local community can develop stronger ties, both at the hardware and software level, with the local community. It can promote distributed generation, reinvestment of the profit and possible deployment of new renewable energy projects or related businesses [39,45]. Out of 28 localities with deployed projects, in 18 cases the investing company was registered in a bigger urban center. Another 10 companies were registered in rural areas, 6 of which were registered in the same locality the project was deployed. Out of six, only two projects were initiated and are managed by the local authorities.

The existing structure of ownership shows that more than three-quarters of the projects are developed by companies registered in a different location than the one where the project is deployed. Out of the remaining, only two villages deployed a renewable energy project managed by the local authorities. This fact underlines the strong dependency of rural development from core urban areas, and the difficulties of new development path creation in peripheral regions.

In addition, we asked the local authorities whether they were the ones who advocated the deployment of the project from their side as well or whether it was solely the investors' decision. Excluding the two villages that implemented their own renewable energy projects, only four other local authorities were actively supporting the deployment of the project from their side as well. In the other 22 cases, the decision to invest was made only by investor without any involvement from the local community side. In this way, majority of solar power projects deployed were projected and implemented rather unilaterally by the investor, without any implication of the local community.

Discussing the role played by the local authorities in the deployment of the project, we asked the representatives to assess the importance of their institution on the deployment of the project. 
The answers are clustered on two extremities, with 18 villages leaning toward the idea that local decision makers had rather limited impact on the decision to deploy the project, while another 11 perceiving a higher impact on the decision to deploy the project. However, if we contrast the data from Figure 6 with the answers local authorities gave once asked what was their specific leverage on the project, we can see that it is strictly reduced to the legal permits they had to remit.

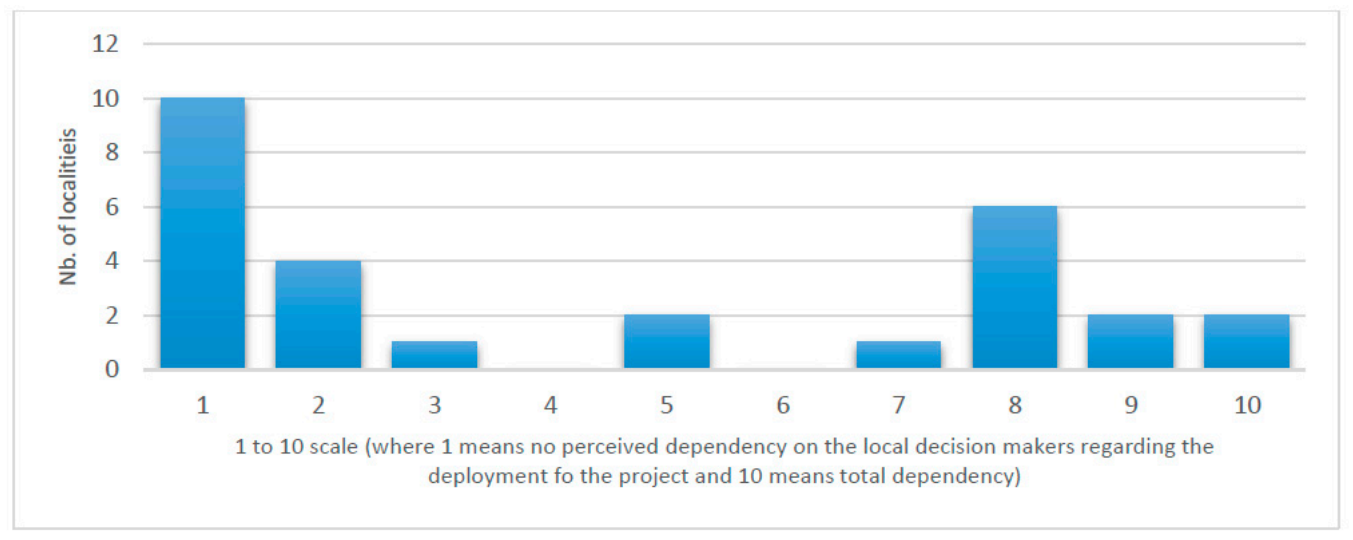

Figure 6. Project's dependency upon the local decision makers.

The mayor of one of the villages that assessed the dependency on local authorities quite high (9) said:

"They (investors) had to obtain the construction notice and the land usage notice from us, without any of those documents it would be impossible for them to start the project."

Similar idea was confirmed by another mayor who mentioned that:

"The law is quite clear about what the investor has to obtain from the local authority and without those permits they simply cannot proceed."

While it may seem that in this way the local authorities can acquire power negotiating the project and its benefits, it is rather a mistaken perception. As highlighted by another respondent who assessed the impact as negligible (1):

"It is true that we have to remit some permits, however it's not like we can decide to remit them or not, if they (investors) fulfill all the conditions stipulated in the law and if there are no major problems, we simply cannot deny them the permits."

This point highlights that overall, unless involved in the project's development and deployment directly, local authorities are not involved in the approval or contestation of the project. Since the permits that have to be granted by the local authority have nothing to do with the level of public/community approval of the project it is hard to even discuss about this aspect. Certainly, local community can have a critical stand against a project by not selling the land to the developer or protesting the development through public marches. However, this type of evolution is rather unfamiliar to the deployment of renewable energy projects in Romania.

The only two cases different where the two villages who own the projects, in their case the whole decision to implement the project is linked to the local authorities so it is clear that the dependency of the project on authorities was graded with 10 by both mayors. However in all the other cases, authorities' leverage is reduced to granting permits for land usage and construction. While it may seem enough to stop a project, it is nevertheless quite difficult for authorities to deny investors those permits if they fulfill all the legally required criteria. 


\subsubsection{Energy Usage and Pressure to Change the Existing Arrangements}

Existing structure of ownership of solar power projects shows that there are few projects started at the local level. In the majority of cases, the investment is made by an external company. Moreover, even at the level of support we see a weak involvement of the local communities with only few villages promoting the development of renewable energy project on their territory. Poor involvement in the ownership and management of the project translates into non-existient hardware innovation. All 28 authorities confirmed that they cannot use the produced energy locally and no real involvement to develop such a solution was seen from the communities' side.

While there is very limited potential for hardware innovation, we observed that the two communities that owned their own solar power projects were actively involved in negotiating and changing the existing energy regulations.

When explaining their undergoing negotiations with the regional and central authorities, the mayor of one of the communes which developed their own solar power project said:

"We cannot use the electricity for ourselves, but it is what we need most of all, we have to find a way to supply ourselves first."

The vice-mayor of the second village who implemented a solar power project stressed that:

"The legislation is restrictive to those who want to use the energy they produce while connected to the national grid, but we know that we have to come up with some solutions to this problem, otherwise why would we have the project in the first place?"

In both cases, representatives confirmed that they are currently negotiating with regional authorities as well as with the regional energy distribution company a possibility to allow communities to locally consume the produced energy.

In this way, out of 28 communities with installed renewable energy projects, only two local authority's representatives acknowledged the need to change the existing energy management structure and start pushing their own agenda. Certainly, it is early to argue that this position leads to practical policy innovation actions, however similar pattern could be observed in the case of Schönau, Germany, where local authorities together with citizens understood the limitations imposed by the existing state of affairs and took action to change the situation [44]. Another example comes from the UK where Seyfang and Haxeltine [17] argue that community-led niche innovation initiatives can foster deeper engagement with relevant actors and thus changing the existing institutional arrangements. In our case, we can see that the ownership structure is connected with the intention to change the policy arrangements. We believe that this attitude is a display of software innovative thinking. While not yet resulting in any legal or administrative changes, it is a clear indicator of the interest and engagement of the project owners to change the rules of the game.

\subsubsection{Initiating Own RES Projects}

Observing the way in which public authorities evaluated their policy role under the influence of the deployed RES project we asked local authorities whether they consider developing a RES project on their own. It is an important indicator of possible administrative innovation because deploying and managing their own renewable energy project requires an assessment of the existing resources, public discussions about the project, finding financing opportunities, acquiring the needed technical knowledge, and finding fitting partners. All those activities are not "policies as usual" for public authorities. There is no legislative basis that would encourage this type of behavior and the existing public policy aimed to encourage the development of community-owned renewable energy projects requires a good knowledge of the renewable energy sector as well as of energy legislation. So even considering and starting the study regarding a possible deployment of a renewable energy project is already an active position. A position that can further lead to administrative/policy innovation as we saw for the case of two communities that own their own project. 
In our questionnaire, we asked local authorities whether they consider developing their own renewable energy project and whether they have done any work in that direction. Out of 28 cases, 16 local authorities confirmed for us that they have considered developing an REP, while 12 said they are not interested in such a project. Within the group that considered developing their own project, we identified three different subgroups. The first group of localities just confirmed that they consider the REP as a possible development path for their communities, however no clear steps were yet undertaken to proceed in that direction. Remaining eight villages moved further than the simple consideration of the project, three of them are looking for the possible mechanisms to finance their project, in all cases the local authorities stressed that they see EU funds as the main possible mechanism to initiate the project. The other five villages concentrated on the assessment of their renewable energy potential and the best technical solution to implement the project.

The two communities that already implemented REP on their own declared that they are currently working on assessing other type of renewable energy resources in order to diversify and develop renewable energy generation facilities in their communities. Moreover, both mayors stressed for us that they consider a type of renewable energy project that would allow them to use the produced energy locally without having to negotiate with central authorities. For that purpose they are currently assessing villages' potential of thermal water and possible feasibility of a micro combined heat and power project.

These results are rather un-expected if we consider that all the public authorities know about the fact that they cannot use the produced electricity and they assessed the impact of the project on the classic development variables quite low. Why would local authorities consider deploying a renewable energy project given the fact that they assessed quite poorly its impact on their community? One possible explanation is related to the possibility of attracting EU financing in this domain. In all three cases which are looking for financing mechanisms, local authorities believe EU financing to be the main possibility for them, thus bringing the EU money is directly associated with clear economic gains for the community, regardless of the project the money are invested in. This expectation relies on a specific public policy developed by the government in 2010 that aims to assist local communities to implement their own REP with financial assistance from the regional development funds [46]. While implemented in 2010, this policy seemed to have a very limited impact on the development of community owned REP, the main issues related to it being the overcentralized logic of application, the unclear implementation procedure, and conflicting legal provisions that were not fully clarified by the government. Regardless of its limitation, local authorities consider it as a viable opportunity for attracting EU founds, at least at the project design phase.

Another possible explanation can be related to the sense of ownership. With the exception of the two villages who manage their own RES project, in all the other cases the project is deployed by a private company, thus developing own renewable energy project could be seen by local authorities as yielding more benefits than if it is deployed by a private agent.

The most interesting is the case of two communities who already own a REP and who cannot benefit fully from it due to legislative and technical constraints. Instead of giving up on the idea of REP they tried to find another type of REP that would fit their needs while also avoiding the existing legislative and technical constraints. Considering the fact that these two villages are also the ones that try to "change the rules of the game" on the policy side, we can say that the ownership of the solar power projects by the local community can lead to a clear display of innovative behavior, especially on the software side.

\section{Conclusions}

Going back to the initial theoretical conceptualization of interaction between renewable energy project-based innovation and rural communities we can state the following:

- Ownership - from the total number of deployed projects only a small part is deployed by the local agents and only two are owned by the local authorities. 
- $\quad$ Power over the agenda setting — while having different attitudes regarding their own influence over the project's deployment unless the project belongs to the local community, we cannot say it will give local decision makers power over political and social agenda setting.

- $\quad$ Usage of the energy - none of the communities with deployed solar power projects are able to use the energy for their own needs.

- $\quad$ Pressure to change the existing regulations-only 2 out of 28 communities are actively involved in discussing and changing the existing energy policies.

- Consideration initiating own renewable energy projects-16 villages would consider developing their own renewable energy project, from which 8 are already either evaluating their RES potential or looking for possible financial sources to support the project.

While looking at the local authorities' perception of the solar power projects' impact on classical development indicators, we focused our attention on the possible interaction between solar power projects and innovation. The latest has an important explanatory weight when discussing processes of peripheralization. Thus, we believe that innovative behavior of the local community can lead to de-peripheralization of that community. Contrary to the existing studies, we found that none of the solar power projects deployed in Northwest Romania had an impact on employment, revenues to the local budget, other related investments, infrastructure development, or regional visibility. This finding requires us to reconsider the economic argumentation of promoting renewable energy projects for generating economic benefits.

Looking however, at the relationship between the solar power projects and innovation, we observed an interesting three-layered process. On the first layer, the pro-active intentions of local communities, more than half of the interviewed local authorities declared that they would like to implement another renewable energy project. Half of them not only are interested in deploying a project but are already investigating the ways to do that. This proactive attitude, while not impacting innovation is nevertheless important to highlight because it can lead to more locally owned and managed projects.

The ownership of the project proved to be quite important, generating the second type of interaction for which we saw clear indications of administrative/policy innovative behavior for two villages. In both cases, the owner of the solar power project was the local authority which understood the policy limitations restricting them from using locally produced energy and took action by starting the negotiations with regional and national authorities to change and adapt the system. Which is an innovative action of changing the software part of the solar power projects, adapting the socio-political realities to the local necessities.

Last layer of the relationship was the hardware innovation. The data from Northwest Romania suggests that there are no cases of hardware/technological innovation in villages with implemented solar power projects. It should not come as a surprise since the technology was "imported" to that space after 2010, thus it would be premature to expect a clear impact on hardware innovation capacity. We believe however that the hardware innovation could follow the software/administrative innovation and could be the most important step in building a strong, innovative relationship between the host communities and deployed renewable energy projects. A possible example of that scenario is the decision of the two villages to look for different REP projects that would allow to use the locally produced energy and avoid the central authorities. If implemented, this solution could be a clear showcase of innovative technological and software behavior.

Discussing about these three-layered interaction we also have to pay attention to the time dimension. Given the recent development in the renewables sphere, it may well be that the full range of effects of the community-REP relationship will reveal themselves in the coming years. We believe however that already at that point we can see, through the lenses of the three layers presented above, a possible pattern of interaction. The presence of the project, even if owned by a private investor, may raise the attention of the local community. Attention that further on can take shape in a community, 
locally owned renewable energy project, which further on can provide local authorities with innovative actions in terms of software and hardware solutions.

We consider that the REP-local community interaction in Northwest Romania provided an important and interesting insight in the innovation processes in peripheral areas, and in estimating the importance of alternatives for economic diversification and de-peripheralization in rural areas.

Acknowledgments: The research leading to these results was conducted in the frame of the project "Socio-Economic and Political Responses to Regional Polarization in Central and Eastern Europe" $\left(\operatorname{RegPol}^{2}\right)$, coordinated by the Leibniz Institute for Regional Geography, Leipzig/Germany. The project received funding from the People Program (Marie Curie Actions) of the European Union's Seventh Framework Program FP7/2007-2013/under REA grant agreement No. 607022.

Author Contributions: Jozsef Benedek introduced the main theories of peripheralization and polarization contributing substantially to the theoretical linkage of theories of technological development and theories of peripheralization. He was involved in designing the methodological chapter of the paper, critically reviewing the proposed methodology suggesting alternative methods to improve the quality of the research. He had an important contribution throughout the analysis and conclusion by reviewing those two thoroughly, suggesting possible ways to connect theoretical arguments with empirical data. Sorin Cebotari wrote the paper (with the exception of the theoretical part defining peripheralization). He directed the theoretical argument by connecting theories of peripheralization and technological development. Sorin Cebotari was primarily in charge of providing the theoretical background for the technological development theories, defining also the main concepts. He designed the methodological tools and collected the data for the empirical analysis. The conclusion part was a joint effort of both authors.

Conflicts of Interest: The authors declare no conflict of interest.

\section{Appendix A}

Table A1. Questionnaire for local authorities regarding deployed solar power project in the territory of their village (translated from Romanian).

\begin{tabular}{|c|c|c|}
\hline & Questions Addressed to Local Authorities & $\begin{array}{l}\text { Indicators Used in } \\
\text { the Paper }\end{array}$ \\
\hline 1 & $\begin{array}{l}\text { Can you tell us approximately in what year the decision to deploy a renewable } \\
\text { energy project in your village was taken? }\end{array}$ & \multirow{4}{*}{$\begin{array}{l}\text { "Connectedness" of } \\
\text { local authorities with } \\
\text { the project. }\end{array}$} \\
\hline 2 & $\begin{array}{l}\text { Can you tell us approximately in what year the decision to deploy a renewable } \\
\text { energy project in your village was taken? }\end{array}$ & \\
\hline 3 & When did the project start its activity "de facto"? & \\
\hline 4 & $\begin{array}{l}\text { For this particular project, what kind of approvals, documents, or authorizations did } \\
\text { the investor get from the local authorities? }\end{array}$ & \\
\hline 5 & $\begin{array}{l}\text { On a scale from } 1 \text { to } 10 \text {, where } 1 \text { means very little and } 10 \text { means a lot, how much } \\
\text { would you say the deployment of the project depended on the local authorities? }\end{array}$ & \multirow{9}{*}{$\begin{array}{l}\text { Power over political } \\
\text { and investment } \\
\text { agenda setting. }\end{array}$} \\
\hline 6 & $\begin{array}{l}\text { Who had the final say regarding the deployment of the project (the mayor's office, } \\
\text { local council, regional authorities, etc)? }\end{array}$ & \\
\hline 7 & Did you know the investor before this particular project? & \\
\hline 8 & Have the local authorities planned for attracting this kind of project to your village? & \\
\hline \multirow[t]{5}{*}{9} & Have you encouraged investors to develop this project through: & \\
\hline & Tax exemption for the rented/bought land, & \\
\hline & Financial assistance from the municipality, & \\
\hline & Renting public lands for an advantageous price, & \\
\hline & Other (please indicate) & \\
\hline 10 & $\begin{array}{l}\text { From what you know, did the people from the community had a negative, neutral, or } \\
\text { positive attitude regarding the project? }\end{array}$ & \\
\hline
\end{tabular}


Table A1. Cont.

\begin{tabular}{|c|c|c|}
\hline & Questions Addressed to Local Authorities & $\begin{array}{l}\text { Indicators Used in } \\
\text { the Paper }\end{array}$ \\
\hline \multirow[t]{8}{*}{11} & $\begin{array}{l}\text { On a scale from } 1 \text { to } 10 \text {, where } 1 \text { means very little and } 10 \text { means a lot, please grade } \\
\text { the following affirmations: }\end{array}$ & \multirow{11}{*}{$\begin{array}{l}\text { Impact of the REP on } \\
\text { socio-economic } \\
\text { indicators. }\end{array}$} \\
\hline & $\begin{array}{l}\text { The solar power project contributed to the development of local } \\
\text { infrastructure (roads, power lines, access roads to remote locations, etc.) }\end{array}$ & \\
\hline & The project increased the revenues to the local budget & \\
\hline & $\begin{array}{l}\text { The unemployment rate went down due to the building and operating } \\
\text { the project }\end{array}$ & \\
\hline & Energy prices decreased as a result of immediate proximity power production & \\
\hline & The locality became more visible on the regional level & \\
\hline & $\begin{array}{l}\text { Because of the project, a series of non-REP related investments also came to } \\
\text { our community }\end{array}$ & \\
\hline & $\begin{array}{l}\text { Project deployment led to an increase participation of the local community in } \\
\text { implementation and financial supporting new renewable energy projects } \\
\text { (even of a smaller scale) }\end{array}$ & \\
\hline 12 & Do you know approximately how many people the project employed? & \\
\hline 13 & $\begin{array}{l}\text { Are there any other investments in renewable energy projects followed the } \\
\text { implementation of the project? }\end{array}$ & \\
\hline 14 & What type of financial contributions do the project pays to the local budget? & \\
\hline 15 & $\begin{array}{l}\text { Do the municipality considers/wants to deploy a renewable energy project of } \\
\text { its own? }\end{array}$ & \multirow{2}{*}{$\begin{array}{l}\text { Initiating own } \\
\text { REP_innovative } \\
\text { behavior. }\end{array}$} \\
\hline 16 & What is done already in order to have your own project deployed? & \\
\hline 17 & If you could change anything related to that project, what would change? & \multirow{3}{*}{$\begin{array}{l}\text { Observing the } \\
\text { indirect effects of the } \\
\text { project-what can be } \\
\text { changed, innovating. }\end{array}$} \\
\hline 18 & $\begin{array}{l}\text { In your opinion, what is the biggest gain for your community related to the } \\
\text { deployment of the project? }\end{array}$ & \\
\hline 19 & What would be the biggest loss related to the project deployment? & \\
\hline 20 & w satisfied are you with the deployment of the project in your locality? & \\
\hline
\end{tabular}

\section{References}

1. European Commission. EU Energy in Figures. In Statistical Pocketbook 2015; European Commission: Brussels, Belgium, 2015; p. 262.

2. Eurostat Newsletter. Renewable Energy in the EU. 2016. Available online: http:/ /ec.europa.eu/eurostat/ documents /2995521/7155577/8-10022016-AP-EN.pdf/38bf822f-8adf-4e54-b9c6-87b342ead339 (accessed on 11 February 2016).

3. Del Rio, P.; Burguillo, M. An empirical analysis of the impact of renewable energy deployment on local sustainability. Renew. Sustain. Energy Rev. 2009, 13, 1314-1325. [CrossRef]

4. OECD. Linking Renewable Energy to Rural Development; OECD Green Growth Studies: Paris, France, 2012; p. 352. Available online: http://dx.doi.org/10.1787/9789264180444-en (accessed on 11 March 2015).

5. Cuellar, A.D. Plant Power: The Cost of Using Biomass for Power Generation and Potential for Decreased Greenhouse Gas Emissions. Ph.D. Thesis, The University of Texas at Austin, Austin, TX, USA, 2009.

6. Del Rio, P.; Burguillo, M. Assessing the impact of renewable energy deployment on local sustainability: Towards a theoretical framework. Renew. Sustain. Energy Rev. 2008, 12, 1325-1344. [CrossRef]

7. ADAS Consulting. Renewable Energy and Its Impact on Rural Development and Sustainability in the UK; Report No. URN 03/886; ADAS Consulting for University of Newcastle: Newcastle, UK, 2003; p. 68. Available online: http:/ /seg.fsu.edu/Library/case\%20of\%20the\%20UK.pdf (accessed on 4 February 2015).

8. Klevas, V.; Streimikiene, D.; Kleviene, A. Sustainability assessments of the energy projects implementation in the regional scale. Renew. Sustain. Energy Rev. 2009, 13, 155-166. [CrossRef]

9. Kammen, D.M.; Kapadia, K.; Fripp, M. Putting Renewables to Work: How Many Jobs Can the Clean Energy Industry Generate? University of California: Berkeley, CA, USA, 2004. 
10. Faulin, J.; Lera-López, F.; Arizkun, A.; Pintor, J.M. Energy policy in renewables and its economic and environmental consequences at regional level: The case of Navarre (Spain). In Energy Policy: Economic Effects, Security Asspects and Environmental Issues; Jacobs, N.B., Ed.; Nova Science Publishers: New York, NY, USA, 2009; pp. 223-256.

11. Dincer, I. Renewable energy and sustainable development: A crucial review. Renew. Sustain. Energy Rev. 2000, 4, 157-175. [CrossRef]

12. McKendry, P. Energy production from biomass (Part 1): Overview of biomass. Bioresour. Technol. 2002, 83, 37-46. [CrossRef]

13. Benedek, J.; Moldovan, A. Economic convergence and polarisation: Towards a multi-dimensional approach. Hung. Geogr. Bul. 2015, 64, 187-203. [CrossRef]

14. Hughes, T.P. The evolution of large technological systems. In The Social Construction of Technological Systems; MIT Press: Cambridge, UK, 1987; pp. 51-82.

15. Bolton, R.P.G.; Foxon, T.J. Infrastructure transformation as a socio-technical process-Implications for the governance of energy distribution networks in the UK. Technol. Forecast. Soc. Chang. 2015, 90, 538-550. [CrossRef]

16. Bolton, R.P.G. Socio-Technical Transitions and Infrastructure Networks: The Cases of Electricity and Heat Distribution in the UK. Ph.D. Thesis, University of Leeds, Leeds, UK, 2011. Available online: http:/ / etheses. whiterose.ac.uk/2176/ (accessed on 3 December 2014).

17. Seyfang, G.; Haxeltine, A. Growing grassroots innovations: Exploring the role of community-based initiatives in governing sustainable energy transitions. Environ. Plan. C Gov. Policy 2012, 30, 381-400. [CrossRef]

18. Transelectrica. Grafic Productia, Consumul si Soldul SEN. Available online: http://transelectrica.ro/widget/ web/tel/sen-grafic/-/SENGrafic_WAR_SENGraficportlet (accessed on 9 June 2016).

19. Transelectrica. Contracte de Racordare. Available online: http://www.transelectrica.ro/documents/10179/ 45094/7productie16.xls/8cac352d-676a-4fbb-9f11-30e8d56a1d4d (accessed on 26 February 2015).

20. Cristea, M. Aplicatii ale Teoriilor si Conceptului de Pol de Crestere in Romania. Ph.D. Thesis, Babes-Bolyai University, Cluj-Napoca, Romania, 2013.

21. Benedek, J.; Cristea, M.; Bartok, B. Regional development and Establishment of Renewable Energy Clousters in Northwestern Region of Romania. Environ. Eng. Manag. J. 2013, 12, $237-244$.

22. Wallerstein, I. The Rise and Future Demise of the World Capitalist System: Concepts for. Comparative Analysis. Comp. Stud. Soc. Hist. 1974, 6, 387-415. [CrossRef]

23. Amin, A. An Institutionalist Perspective on Regional Economic Development. Int. J. Urban Reg. Res. 1999, 23, 365-378. [CrossRef]

24. Bathelt, H.; Glückler, J. Resources in Economic Geography: From Substantive Concepts towards a Relational Perspective. Environ. Plan. A 2005, 37, 1545-1563. [CrossRef]

25. MacKinnon, D.; Cumbers, A.; Chapman, K. Learning, innovation and regional development: A critical appraisal of recent debates. Prog. Hum. Geogr. 2002, 26, 293-311. [CrossRef]

26. Hadjimichalis, C.; Hudson, R. Contemporary Crisis across Europe and the Crisis of Regional Development Theories. Reg. Stud. 2014, 48, 208-218. [CrossRef]

27. Boschma, R.; Martin, R. Editorial: Constructing an evolutionary economic geography. J. Econ. Geogr. 2007, 7, 537-548. [CrossRef]

28. Martin, R. Rethinking regional path dependence: Beyond lock-in to evolution. Econ. Geogr. 2010, 86, 1-27. [CrossRef]

29. Dawley, S. Creating New Paths? Offshore Wind, Policy Activism, and Peripheral Region Development. Econ. Geogr. 2013, 90, 91-112. [CrossRef]

30. Kuhn, M. Peripheralization: Theoretical Concepts Explaining Socio-Spatial Inequalities. Eur. Plan. Stud. 2014, 13, 1-12. [CrossRef]

31. Walker, G.; Cass, N. Carbon Reduction, "The Public" and Renewable Energy: Engaging with Socio-Technical Configurations. Area 2007, 39, 458-469. [CrossRef]

32. Foxon, T.J. Technological and Institutional "Lock-In" as a Barrier to Sustainable Innovation. 2002. Available online: http:/ / www3.imperial.ac.uk/icept (accessed on 19 January 2015).

33. Buchan, D. The Energiewende-Germany's gamble. Oxf. Inst. Energy Stud. 2012, 26, 1-23.

34. Goldthau, A. Rethinking the governance of energy infrastructure: Scale, decentralization and polycentrism. Energy Res. Soc. Sci. 2014, 1, 134-140. [CrossRef] 
35. Ackermann, T.; Andersson, G.; Soder, L. Distributed generation: A definition. Electr. Power Syst. Res. 2001, 57, 195-204. [CrossRef]

36. Legea nr. 220 din 27 October 2008. Available online: http://leg-armonizata.minind.ro/leg_armonizata/ energie/pdf/Legea_220_2008_R_28102011.pdf (accessed on 27 October 2008).

37. Popovici, V. 2010 power generation sector restructuring in Romania-A critical assessment. Energy Policy 2011, 39, 1845-1856. [CrossRef]

38. Cebotari, S. Romanian electricity market in the light of fast development of renewable energies: General presentation and critical assesment. In Perspectives of Renewable Energy in the Danube Region, Proceedings of Perspectives of Renewable Energy in the Danube Region Conference, Pecs, Hungary, 26-27 March 2015; Ortiz, W., Somogyvari, M., Varju, V., Fodor, I., Lechtenbohmer, S., Eds.; Molnar Nyomada: Pecs, Hungary, 2015; pp. 113-125.

39. Yildiz, Ö. Financing renewable energy infrastructures via financial citizen participation: The case of Germany. Renew Energy 2015, 68, 677-685. [CrossRef]

40. Forta de Munca in Romania: Ocupare si Somaj; Institutul National de Statistica (INS): Bucharest, Romania. Available online: http://statistici.insse.ro/shop/?page=catD\&lang=ro\&category_id=3 (accessed on 15 March 2015).

41. Situatia Veniturile si Cheltuielilor Unitatilor Administrativ-Teritoriale in Perioa 1999-2014; Ministerul Dezvoltarii Regionale si Administratie Publice: Bucharest, Romania. Available online: http://www.dpfbl.mdrap.ro/sit_ ven_si_chelt_uat.html (accessed on 15 March 2015).

42. Kohr, R.L.; Games, P.A. Robustness of the analysis of vairance, the Welch procedure and a box procedure to heterogeneous variances. J. Exp. Educ. 1974, 43, 61-69. [CrossRef]

43. HG nr. 90/2008. 109/12.II.2008. p. 12. Available online: http://www.electricafurnizare.ro/wp-content/ uploads/2012/05/HG-90_2008-Regulament-racordare-utilizatori.pdf (accessed on 5 May 2015).

44. Frondel, M.; Ritter, N.; Schmidt, C.M.; Vance, C. Economic Impacts from the Promotion of Renewable Energy Technologies: The German Experience. Energ. Policy 2010, 38, 4048-4056. [CrossRef]

45. McLennan, W.; Antebi, T. How One Town Foiled Energy Giant "Bribes" over Renewable Grid. Ecologist 2011. Available online: http://www.theecologist.org/News/news_analysis/875713/how_one_town_foiled_ energy_giant_bribes_over_renewable_grid.html (accessed on 29 April 2016).

46. Ghidul Solicitantului. Sprijin Financiar Acordat Pentru Proiectele de Investiţii în Valorificarea Resurselor Regenerabile de Energie Pentru Producerea Energiei Verzi în Cadrul Axei 4 a Programului Operaţional Sectorial Creşterea Competitivităţii Economice; Organismul Intermediar Pentru Energie: Bucharest, Romania, 2010. Available online: http://old.fonduri-ue.ro/poscce/fonduri_structurale/pdf/Ghid_IMA_final_martie_2010. pdf (accessed on 16 November 2016).

(C) 2017 by the authors. Licensee MDPI, Basel, Switzerland. This article is an open access article distributed under the terms and conditions of the Creative Commons Attribution (CC BY) license (http:/ / creativecommons.org/licenses/by/4.0/). 